\title{
The origins of the Homicide Act 1957
}

\author{
J Higgins Regional Forensic Psychiatry Service, Liverpool
}

\section{Editor's note}

This paper traces the history of the concepts of insanity and diminished responsibility in English law. Insanity as a defence in Law has two components, and these two components developed quite separately. The idea that an insane person may not know what he or she is doing when he or she commits an offence, and is for this reason not guilty, goes back to the thirteenth century. The other component, which developed in the seventeenth century, was known as the 'right-wrong test'. According to this a person who commits an offence may be not guilty on the grounds that he does not know that what he is doing is wrong. The concept of diminished responsibility originated in the middle of the nineteenth century and was developed in Scottish law. It was not until almost a century later that it was accepted South of the Border.

I propose to give a brief historical review of the regard given to matters psychiatric in criminal cases. The presumption of responsibility for an act done is integral to any system of law, but arrangements have always had to be made for those for whom it is quite obvious that such a presumption is debatable. The Homicide Act 1957 is but one test of this issue.

\section{Early history}

In Saxon and Norman times the basis of law was compensation by the convicted person, or his family, to his victim. In a country with such a small population, so widely scattered, the numbers of the mentally abnormal committing any offence, let alone homicide, must have been very small. The need to devise a special system for coping with mentally abnormal offenders who had committed serious offences was therefore not great.

Prior to the eleventh century 'one had to buy off the spear or bear it', the price being determined not by culpability (even accident was no excuse), but by the seriousness of the wrong or the status of the victim. However, by the eleventh century it was felt that there

\section{Key words}

Mentally abnormal offender; forensic psychiatry; insanity; diminished responsibility; homicide; mental illness. were certain serious wrongs, amongst them murder, which were 'botless', that is they could not be expiated by compensation but had to be punished by death and forfeiture of property. Nevertheless for both groups of offences, botless and non-botless, there was no assessment of culpability or responsibility - a sort of strict liability operated. It appears that the mentally abnormal offender's family would have to pay compensation for any act done by him, including homicide, and thereafter take care of him - 'an insane person should be guarded and treated leniently by his parents'.

\section{The twelfth to the eighteenth centuries}

Only when the Plantagenets succeeded in imposing a central control over England, for political rather than criminological reasons, did the King take an interest in the most serious offences committed in his realm.

By the time of Henry II trial by ordeal was gradually being replaced by trial by jury and a centralised system of prosecution in serious cases had been established. Insane offenders had to be reported to the King because only he could interfere with the process of law and excuse the accused from the automatic penalty for his offence. The disposal at this time was therefore, first a decision by a jury, who knew the defendant well, and that he was insane, followed by a royal pardon and exemption from punishment. In the mid-thirteenth century Bracton commented, however, that 'a crime is not committed unless the will to harm be present' and 'what can be said of the child and the madman; for one is protected by his innocence of design, the other by the misfortune of his deed' (1).

The next important source from which information can be drawn on the handling of mentally disordered offenders is Sir Mathew Hale who was not only Lord Chief Justice of England, but also well versed in the psychological theories of his time. Hale died in 1676 leaving behind him a text entitled History of the Pleas of the Crown (2) in which he describes the law and practice of his day. By this time there was a greater sophistication in the appreciation of mental disorder and Hale distinguishes 'idiocy' (by which he means what we now call mental impairment and severe mental impairment) from dementia accidentalis with its 
sub-divisions of episodic lunacy and persisting phrenesis or madness (by which he probably means manic-depressive disease and schizophrenia respectively) from dementia affectata which corresponds to toxic organic states induced by alcohol or drugs. Despite this increase in sophistication, the test for insanity in the courts had changed little and was still very strict and based on cognitive abilities. Bracton, four centuries earlier, had defined the 'furious man - not much above the beasts which lack reason' (3). Hale, in his turn, wrote 'that they have not the use of understanding, and act not as reasonable creatures, but their actions are in effect the condition of brutes' (2). Hale did however recognise the concept of partial insanity of the mind. This concept, despite the degree of disability which might occur, held that the accused acted with 'as great an understanding as ordinarily a child of 14 hath' and 'such a person as may be guilty of treason or a felony' (2).

Nevertheless in all but the most exceptional cases it must have been quite clear that in homicides the madman obviously meant to kill or at least seriously injure his victim yet, throughout this period, juries were, with the approval of the judiciary, acquitting people who committed insane but intentional acts. Perhaps the fact that madmen were being compared to children under the age of 14 , suggests that it was an inability to appreciate that the nature and quality of the act was wrong that was the handicap, extrapolating from a child's inability to tell right from wrong - the right-wrong test as it came to be called.

Hale also indicated that by the seventeenth century, courts were being left to deal with the obviously severely mentally disordered offender without remitting him to be pardoned by the King; the court itself bringing in a judgement of acquittal (4). Following such an acquittal the defendant was returned to his family who were charged with looking after him. Hale did not make it clear what happened if the accused was unlucky enough not to have a relative who was willing or able to look after him. Blackstone had however earlier explained that 'persons deprived of their reason might be confined until they recover their senses, without waiting for special authority from the Crown' adding that at this time there was a procedure which 'had been chalked out for imprisoning, chaining and sending them to their proper home' (5). In practice this involved the sending of such defendants to jail as the only secure place available. Until the end of the seventeenth century, when one was founded in Bristol, only London was served by a public madhouse, Bethlem.

\section{The eighteenth century}

The eighteenth century was punctuated by a number of trials of considerable importance which generated discussion of the issues involved. These cases illustrate that while the test for insanity remained strict in theory, its interpretation in practice was very variable; the decision being influenced by factors other than mental disorder.

The first of these cases was that of Arnold, who was probably a paranoid schizophrenic, who attempted to murder Lord Onslow (6). The summing up showed that Bracton's criteria of insanity, ie total deprivation of reason, was still the foundation of the insanity test, but 'brute', meaning animal as opposed to human, had now become 'brute or wild beast', and the tendency to talk of infants and madmen synonymously was quite evident. Thus the test for insanity was being broadened to include not only whether the accused knew what he was doing, but also whether he was able to distinguish whether he was doing good or evil. Arnold was found guilty.

The next case is that of Stafford who stabbed a porter with a sword. The evidence for any psychosis was very thin and if he were deluded at all, it had little to do with the assault which was done in irritation and anger. $\mathrm{He}$ was acquitted (7).

Then there was the case of Ferrers in 1760 . He was an earl, and was therefore tried before the House of Lords for the murder of his factor (6). Evidence for insanity was extremely weak and what seems to have been argued was irresistible impulse. This was not accepted and he was unanimously convicted after the very briefest deliberation of his peers.

In the case of Walker (8), a pauper who had murdered his wife, again the evidence for psychosis seems to have been weak but the judge in summing up made no mention of 'wild beasts'. Anticipating a successful defence of irresistible impulse, he said 'rage which is the affect of distemper is brought upon them by the act of God, and not by themselves, and they are not answerable for what they do in these moments'. Walker was acquitted.

Finally there is the case of Broadric (8), a young woman who shot her lover who had deserted her to remarry. She pursued him and shot him and after giving herself up she was found to have another pistol which she intended to turn on herself. No convincing evidence of insanity was led nor could it be argued that she did not know or intend what she was doing. Nevertheless she was acquitted on the grounds of insanity, to the acclamation of the court.

Although defences of insanity were rare occurrences, their frequency was increasing, and in the eighteenth century the general public as a whole had become more aware of the social consequences of mental disorder. New public hospitals for the insane were opened which led shortly to the founding of county asylums. There was increasing criticism of the treatment of lunatics in existing establishments such as Bethlem and there was great disquiet about many of the private madhouses.

The eighteenth century therefore, although it has often been seen as a time when little change occurred, was perhaps a necessary period of reconsideration which led to the noted developments of the nineteenth century. 


\section{The nineteenth century}

The nineteenth century got off to a flying start with the case of Hadfield in 1800 (10). Hadfield fired a pistol at George III in a theatre just missing him. He was accordingly charged with treason and was therefore provided with a counsel and time to prepare his defence. Although witnesses testified to some preparation for the act it was not difficult to show that Hadfield was markedly mentally abnormal. He had suffered a penetrating head injury, had a history of bizarre behaviour and bizarre ideas, and seems to have been incoherent when discussing the motives for the assault. He was however sensible on everyday topics so that it was difficult to argue either that he satisfied the right-wrong test, or that he was not aware of the nature of his act. Nevertheless Erskine, his counsel, managed to achieve an acquittal, helped no doubt by the directions of the trial judge, who was aware that a Bill with retrospective effect was being hastily put through Parliament to ensure that an acquittal would not mean that Hadfield would go free. From this Bill on, a plain acquittal was no longer possible - only an acquittal on the grounds of insanity, ie the 'Special Verdict' after which the accused was to be kept 'in strict custody, in such a place and in such a manner as the Court shall deem fit, until His Majesty's Pleasure be known' (11). This Special Verdict had limited application to treason, murder and felony - but not to misdemeanours.

In contrast to Hadfield's case was that of Bellingham who in 1812 shot and killed the Prime Minister, Spenser Percival (12). He seems to have been a paranoid schizophrenic whose paranoid delusional ideas were revealed in his attempts at the trial to enlarge at length upon an extensive system of persecution which he felt he was subject to. In this case the trial judge's directions were extremely strict and the jury did not accept the remarkable and successful defence Erskine had used in Hadfield's case, that the attack had been motivated by a delusion. Bellingham was executed to some later judicial disquiet.

The next milestone was McNaughton's case in 1834 (13). Daniel McNaughton, who had a long history of delusional beliefs of persecution by Tories, shot and killed Drummond, Prime Minister Peel's secretary, in mistake for Peel, the Tory Prime Minister.

In the nineteenth century, prior to McNaughton's case the relationship between insanity and legal responsibility had become the subject of books by psychiatrists, the most notable amongst these being an American, Isaac Ray (14). His view was that both the right-wrong test, and a purely cognitive assessment of knowledge of what was being done were much too narrow tests of criminal responsibility. He suggested that what needed to be shown was that 'the mental unsoundness ... embraced the criminal act within it's sphere of influence'.

Ray's views were extensively quoted at McNaughton's trial particularly his view that not all insanity was as 'furious' as that described in Hale and that delusional ideas could exist in a setting of otherwise unremarkable behaviour and then erupt into serious violence (14). (Shades of Sutcliffe?) Cockburn, McNaughton's counsel, attempted to show that McNaughton suffered from a version of such partial insanity, that this was within the law's interpretation, and that it excused him. He argued that this partial insanity took away his self-control and, like Erskine before him, he had to convince the judges to accept this test of insanity without them realising what they were doing. His view was accepted and the Special Verdict brought in. McNaughton was sent to Bethlem and then to Broadmoor.

There was a public outcry at the verdict and at 'the latitude that medical men were apt to attribute to the notion of insanity' so the House of Lords asked the judges for their view of the law. After three months deliberation, they gave answers to the five questions posed to them (15). Part of the combined answer to questions 2 and 3 are the phrases that provide the guidance for juries (known as the McNaughton Rules). The test of insanity which was produced was a combination of the wild-beast test and the right-wrong test and on the basis of the test devised, McNaughton would surely have been convicted.

It was not long before the Rules were strongly criticised, mainly because of their cognitive nature and particularly because they did not make any allowance for the concept of 'irresistible impulse' which had become a fashionable preoccupation. Nevertheless, in some later nineteenth century cases the issues of selfcontrol, (or rather the lack of it) and the knowledge of right and wrong, tended to be blurred and juries duly produced the Special Verdict. Such incidents continued until the case of True in 1922 when the Court of Appeal, confirming his conviction, firmly pointed out that the trial judge's summing up, which told the jury that irresistible impulse could have constituted insanity, was far too generous to the defendant and was not the law (16). However, by the time of the Royal Commission on Capital Punishment, commonly known as the Gowers Commission, which sat between 1949 and 1953, witnesses, psychiatrists and judges, were prepared to state openly that in many, but not all cases, the Rules were being widely stretched. Judges and juries seemed to be asking themselves if the accused had been seriously mentally disordered at the time of the act and if so decided in his favour without recourse to the Rules. Lord Cooper, Lord Justice General of Scotland, stated quite baldly that in reality what juries asked themselves was 'is this man mad or not?' (17). Despite the Gowers Commission suggestions on how the Rules might be altered they have remained as they are; criticism of them and the bending of them no longer being an issue because insanity has become a more rare defence.

\section{The law in Scotland and diminished responsibility}

In the sixteenth century, law on insanity in Scotland 
was still being interpreted as in England. In a case of 1554, the defence talks of a man as 'furious', 'wanting reason', 'that he is comparable to an infant, pupil or beast, so that he could not commit any deed that might be liable to punishment' (18).

Sir George MacKenzie (1636-1691), otherwise known as the Bloody MacKenzie, for good reason, who was a contemporary of Hale, was, like most Scots of his time, much more influenced by continental jurists and their views on responsibility than were English jurists. In contrast to Hale he seems, in his writings, to have been amenable to the idea of partial insanity: 'It may be argued that since the law grants a total impunity to those that are absolutely furious, therefore it should by the rule of proportions lessen and moderate the punishments of such as though they are not absolutely mad yet are hypochondrick and melancholy to such a degree that it clouds their reason' (19).

Nigel Walker suggests that it is at this point that the Scots lawyers began to diverge from the practice in England (20). The acceptance of partial insanity in practice did not necessarily result in juries producing verdicts of not guilty, but did result in juries being asked, or even instructed, to suggest a pardon following a finding of guilty. Baron Hume, not much before McNaughton's trial, stated that even if the accused had known he was committing murder and that murder was in general wrong he could still be 'absolutely mad - as if he had lost all true observation of the facts, all understanding of the good and bad intentions of those around him' - all of which would have fitted McNaughton's case well (21).

The most radical innovation occurred in the summing up by Lord Deas in the case of Dingwall in 1867 (22). Dingwall was a chronic alcoholic. He had been in India and had suffered sunstroke, he had seizures, and he regularly showed evidence of delirium tremens (DTs). He was known locally as 'the mad laird' though not so mad as to allow doctors to certify him as a lunatic. At Hogmanay he drank a great deal of whisky, returned home and quarrelled with his wife and retired to bed. He got up later without comment and stabbed her with a carving knife. His wife, who took some time to die, said that previously in such drunken states he had often threatened to take his life and hers.

In summing up Lord Deas stated the position in law: 'If he had sufficient capacity to know and did know that his act was contrary to law and punishable by law, then he should be convicted'. But, and here is the innovation, could, he asked the jury, the offence be anything short of murder? Though it was very difficult for the law to recognise it as anything else he could not say that it was beyond the province of the jury to find a verdict of culpable homicide. Principal amongst his reasons for considering this was that Dingwall had had sunstroke, had had occasional alcoholic epileptic seizures, had had repeated DTs, and 'if weakness of the mind could be an element in any case in the question between murder and culpable homicide, it seemed difficult to exclude that element here'. Lord Deas said that he had considered the whole case most carefully and thought that the state of mind of the prisoner might be an extenuating circumstance, leading not to an acquittal on the grounds of insanity but to a verdict of culpable homicide for which there was flexibility in sentencing (22).

The jury took his line and Dingwall was convicted of culpable homicide and sentenced to ten years' imprisonment.

What Lord Deas had done would have been unthinkable in an England so tied to a settled definition of murder and to such a strict test of criminal insanity. In Scotland the McNaughton Rules did not apply, and the difference between culpable homicide and murder was less clearly defined.

The term diminished responsibility seems to have been first used by Lord Bell in Braid's case in 1835 (23). The advantages of flexibility as shown in Lord Deas's innovation, were mirrored by the comments of Stephen in England, who in 1883, suggested that when madness was proved, one of three verdicts could be brought in: 'Guilty; Guilty, but his powers of selfcontrol were diminished by insanity; Not Guilty, on the grounds of insanity' (24). His suggestion unfortunately was not taken up and the issue of diminished responsibility lay dormant in England until it was taken up by the Royal Commission on Capital Punishment, the Gowers Commission, in 1949 (17).

\section{The Gowers Commission}

The Commission reviewed the Scottish procedures . It commented that if a person charged with murder suffered from a mental weakness or abnormality bordering on insanity to such a degree that his responsibility was substantially diminished, the crime may be reduced from murder to culpable homicide'.

Despite reviewing seven selected and hard cases where the defence had succeeded and commenting that all would have been found guilty of murder in England, the Commission was reassured that the doctrine had not been pressed too far in Scotland and seemed to work well.

The Commission thought the arguments in favour of the introduction of the doctrine of diminished responsibility into England were strong: there are imperceptible gradations between insanity and sanity; there is no clear boundary between responsibility and irresponsibility; other jurisdictions, particularly on the Continent, recognised degrees of responsibility; an acceptance of the doctrine would bring the law into closer harmony with the facts and would enable the courts to avoid passing sentence of death in numerous cases in which it would not be carried out, as the Home Office would grant a reprieve.

On the other hand, there was a fear that juries would be too lenient, even though Scottish juries did not find it too difficult to interpret the doctrine, and even though there was a general agreement that the 
procedure worked satisfactorily.

Having then, in my view, convincingly argued in favour of the introduction of diminished responsibility the Commission promptly rejected it - on the peculiar ground that if the doctrine were brought in it would have to be a general doctrine applying to all forms of offence and that, as the remit of the Commission was that of considering capital punishment for murder, the Commission could not make such a wide-ranging recommendation. In the interest of not suggesting a new general principle, it was not prepared to suggest a special category of mitigating circumstance in cases of murder. The Commission seems to have completely overlooked that a special defence had existed for years - infanticide.

\section{The birth of the Homicide Act}

Little of the Commission's report was received with enthusiasm by the Government. However, the Government's unwillingness even to suggest alternatives provoked interested parties into taking the initiative. A committee of barristers and legally qualified MP's was set up under the Chairmanship of Sir Lionel Heald to discuss all the issues covered by the Commission. Not surprisingly this Committee found the insanity defence the most difficult, nevertheless, it firmly recommended no change in the McNaughton Rules, and the introduction of diminished responsibility. Later that year the Government produced its Homicide Bill containing wording identical to that of Section 2(1) in the subsequent Act. All amendments were then resisted during its passage through Parliament.

Having now got as far as its birth I do not intend to describe how the Act has grown up. However, I cannot avoid the observation that, as is well known in medical circles, things run in families.

The ancestors of the Act seem to have been unreliable, uncertain individuals about whom there were many and conflicting opinions, few of them complimentary. It is not surprising therefore that we are holding yet another case conference to decide upon this adolescent's recent behaviour and to suggest how it might be altered in the future.

Finally, if I may be excused another metaphor, Nigel Walker in his masterly two volumes, Crime and Insanity in England (20), to which I am greatly indebted for this paper ends the first book with a chapter entitled The End of an Old Song, a summary of events leading to the Homicide Act 1957.
In 1968 when the book was published he could perhaps not have anticipated that the Butler Committee would try to sing yet another verse. Perhaps meetings like this, of doctors and lawyers, are further attempts to try and get the words and music to match. I doubt however, whether either party will ever rest content that we have completed a masterwork.

$D R \mathcal{F}$ Higgins $M B$ ChB FRCPsych DPM is Consultant Forensic Psychiatrist, Mersey Regional Health Authority.

\section{References}

(1) Bracton. Woodbine ed. De legibus et consuetudinibus Angliae. Yale: Yale University Press, Oxford University Press, 1915.

(2) Hale, Sir M. Historia placitorum coronae. London: 1736: ch IV.

(3) See reference (1): (n 20), IV, 308.

(4) See reference (2): ch III.

(5) Blackstone W. Commentaries on the laws of England. London: 1765-9 Book IV, ch 2.

(6) Howell T B. A Complete collection of State trials and proceedings for high treason and other crimes and misdemeanours. London, 1816-1828.

(7) Old Bailey Sessions Papers for July 14-17, 1731.

(8) Old Bailey Sessions Papers Case 388, 1784.

(9) The Times $1795 \mathrm{Jul} 18$.

(10) R v Hadfield (1800) 27 State trials (new series) at 1281.

(11) An Act for the Safe Custody of Insane Persons charged with Offences, 180040 Geo III, c 94

(12) Old Bailey Sessions Papers Case 433, 1812.

(13) MacDonell J, ed. State trials, new series 1820 , etc. London: Eyre and Spottiswode.

(14) Ray I. A treatise on the medical jurisprudence of insanity. London: 1839.

(15) R v McNaughton (1843) 10 CR and Fin 200; 4 St Tr NS 847.

(16) R v True (1922) Cr App R 164

(17) Report of the Royal Commission on Capital Punishment, 1949-53. Cmnd 8932.

(18) Arnot H. A collection and abridgement of celebrated criminal trials in Scotland. 1536-1784, II. Edinburgh, 1833 ed, pt 2: 363.

(19) MacKenzie Sir G. A discourse upon the laws of Scotland in matters criminal. Edinburgh, 1674.

(20) Walker N. Crime and insanity in England. Edinburgh Edinburgh University Press, 1968: 140.

(21) Hume Baron. Commentaries on the law of Scotland respecting the descriptions and punishment of crimes. Edinburgh, 1794.

(22) H M Adv v Dingwall, 1867, 5 Irv.

(23) Braids Case, 1835, I Hume Com ch I.

(24) Stephen, Sir James F. History of the criminal law of England. London, 1883. 